\title{
The Effect of Emotional Intelligence, Quality of Work Life, and Stress on Job Satisfaction and Turnover Intention among the Employees
}

\author{
Tossy Aryanto ${ }^{1}$, Moch. Asmawi ${ }^{2}$, Mansyur Ramly ${ }^{3}$ \\ ${ }^{1}$ Postgraduate Doctoral Programme, Jakarta State University, \\ Jl. Rawamangun Muka, East Jakarta, DKI Jakarta 13220 \\ ${ }^{2}$ Professor, Faculty of Sport Science, Jakarta State University, \\ J1. Pemuda No.10, Rawamangun, East Jakarta, DKI Jakarta 13220 \\ ${ }^{3}$ Professor, Faculty of Economic, Indonesia Moslem University, \\ J1. Urip Sumoharjo KM.5, Panakukkang, Makassar, South Sulawesi 90231
}

\begin{abstract}
This study was conducted to find out the information about the effect of emotional intelligence, quality of work life, and stress on job satisfaction and turnover intention among the employees of IPC Port Equipment in Indonesia. The study uses a sample of 175 employees from headquarter and 11 branches of IPC Port Equipment. The empirical testing indicated that both emotional intelligence and quality of work life have positive effect on job satisfaction and have negative effect on turnover intention; stress has negative effect on job satisfaction and has positive effect on turnover intention; job satisfaction has negative effect on turnover intention.
\end{abstract}

Keywords: emotional intelligence, quality of work life, stress, job satisfaction, turnover intention.

\section{Introduction}

IPC Port Equipment (IPC-PE) is a subsidiary of Indonesia Port Company (IPC), which is engaged in maintenance and repair of various port equipment, and has an important role in ensuring the successful operation of the four state-owned port companies in carrying out its operations. Effectiveness and efficiency of IPC-PE in managing Human Resources (HR) became one of the key and strategic position in achieving business optimization. Currently IPC-PE is faced with the problems of turnover intention and job satisfaction of employees which is allegedly caused by several things such as the employee's inadequate emotional intelligence, the quality of work life in the work environment is still low and high stress levels that occur in employees. This study was conducted during August to December 2017.

\section{Literature Review}

According to Mathis and Jackson (2008), turnover can be classified into the following types: 1) Involuntary and voluntary turnover, 2) Functional and dysfunctional turnover, and 3) Uncontrollable and controllable turnover. ${ }^{[1]}$ Factors influencing the turnover intention by Price in Lewis (2008) consist of: 1) Environmental factors consisting of kinship responsibilities to the environment, and employment opportunities, 2) Individual factors, consisting of job satisfaction, commitment to institutions, behavior of seeking opportunities or vacancies, intention to remain, general training/competence improvement, willingness to work hard, and negative or positive feelings towards his work, 3) Structural factors, consisting of autonomy, justice, work pressure, remuneration, possibility of promotion, work routine, and social support. ${ }^{[2]}$ The Intention turnover indicators according to Chen and Francesco (2000) include thoughts of getting out of the organization and work, the desire to seek other jobs, and the desire to leave the organization 
in the coming months or the desire of an employee to try to split up and move on to another organization. ${ }^{[3]}$

According Armstrong (2006), job satisfaction refers to the attitudes and feelings a person has about the job they have. Furthermore, Armstrong explained that the level of job satisfaction is influenced by intrinsic and extrinsic motivational factors, the quality of supervision, social relationships with work groups and the level of success and failure of individuals in their work. Research conducted by Purcell, et.al. (2003) in Armstrong finds the main factors affecting job satisfaction namely, career opportunities, employment effects, teamwork, and job challenges. ${ }^{[4]}$ Over the years five dimensions of work have been identified to represent the characteristics of a job most effectively responded to by workers or employees, namely: 1) the work itself, 2) Pay/salary, 3) Promotional opportunities, 4) Supervision, and 5) Co-workers (Luthans, 2011). ${ }^{[5]}$

Emotional intelligence is the ability to feel and understand more effectively the emotional sensitivity that includes the ability to motivate yourself or others, self-control, able to understand the feelings of others effectively, and able to manage emotions that can be used to guide the mind to make the best decision. According to Weisinger (2006), emotional intelligence is defined as an instrument to solve problems with colleagues, make deals with customers, criticize superiors, complete tasks to completion, and in other challenges that can undermine success. ${ }^{[6]}$ According Kinicki, et.al. (2010), emotional intelligence consists of 5 dimensions, namely: 1) Self-awareness, 2) Self-management, 3) Selfmotivation, 4) Empathy, 5) Social skills. ${ }^{[7]}$ Goleman (2009) explains that Salovey combines the eight basic intelligence coined by Howard Gardner into the basic definition of emotional intelligence and extends it into five main aspects: 1) Knowing one's emotion, 2) Managing emotions, 3) Motivating oneself, 4) Recognizing emotions in others, 5) Handling relationship (relationship building). ${ }^{[8]}$
Quality of work life is a form of philosophy applied by management in managing the organization in general and human resources in particular. Taylor (2008) in Armstrong explains that the quality of working life is related to extrinsic factors of fundamental work: wages, hours and working conditions and various intrinsic factors rather than the work itself. ${ }^{[9]}$ According to Cascio (2003), the components of quality of work life are: 1) Employee involvement, 2) Career development, 3) Pride, 4) Equitable compensation, 5) Job security, 6) Wellness facilities, 7) Safety of the work environment (safe environment), 8) Conflict resolution, and 9) Communication. ${ }^{[10]}$ Indicators of measuring the quality of working life developed by Walton (1998) are: 1) Growth and development, 2) Participation, 3) Innovative rewards system, and 4) Work environment. ${ }^{[11]}$

Stress is a condition where there is a discrepancy between the expected or desired by a person with the gain, where there is a gap between the demands of the environment and the individual's ability to fulfill it that is considered potentially dangerous, threatening, disturbing and uncontrollable or exceeding that individual's ability. Hellriegel and Slocum (2011) explain that stress is the excitement, anxiety, and/or physical tension that occurs when a claim or pressure placed on a person is considered to exceed a person's ability to overcome it. ${ }^{[12]}$ Schermerhorn, et.al.(2002) mentions stress sources are: 1) Workrelated stressor that include task demands, role ambiguity, role conflict, ethical dilemma, interpersonal problems, career development, and physical setting, 2) Personal and non-work stress factors such as family events (e.g. birth of a new child), economic difficulties (e.g. investment losses), and personal affairs (e.g. family divorce). ${ }^{[13]}$

\section{Hypotheses}

Based on discussion in theoretical foundation, it has led to a brief examination of the existing literature and the development of hypotheses in this research, they are: 
H1: Emotional intelligence has a direct positive effect on job satisfaction.

H2: Quality of work life has a direct positive effect on job satisfaction.

H3: Stress has a direct negative effect on job satisfaction.

H4: Emotional intelligence has a direct negative effect on turnover intention.

H5: Quality of work life has a direct negative effect on turnover intention.

H6: Stress has a direct positive effect on turnover intention

H7: Job satisfaction has a direct negative effect on turnover intention.

\section{Method}

The research method used is survey method. Data collection in this study through the dissemination of questionnaires to respondents who are samples of the employee population of IPC-PE. A sample of 175 was selected by proportional random sampling with the aim of distributing the sample evenly and represented proportionately in the head office and 11 branches of IPC-PE. Data were collected by a closed questionnaire containing a number of statements prepared with an answer option using a variable measurement scale. To ensure the validity and reliability of the research instrument, the instrument test was conducted using 30 respondents $(n=30)$ samples taken from the population at IPC-PE. The instrument test is performed by Pearson Product Moment correlation formula for validity testing and Cronbach Alpha formula for reliability calculation. At the research stage, the rate of return of the questionnaire reached $100 \%$.

\section{Discussion}

\subsection{Testing Requirements Analysis}

Prior to performing path analysis, there are several requirements that must be met that include, 1) Normality of estimated regression error test and 2) Significance and Regression Linearity Test.

\subsubsection{Normality of Estimated Regression Error Test}

Tests of regression analysis require regression estimates to be obtained from normally distributed populations. The normality test of sample data was performed on regression error estimation of dependent variable on independent variable by using Kolmogorov-Smirnov test with hypotheses of statistical test of normality as follows,

$-\mathrm{H}_{0}=$ The estimated error population is normally distributed

$-\mathrm{H}_{1}=$ Estimated error population is not normally distributed

With the testing criteria,

- If $\mathrm{D}_{0} \leq$ Dtable then $\mathrm{H} 0$ is accepted

- If $\mathrm{D}_{0}>$ Dtable then $\mathrm{H} 0$ is rejected

Furthermore, with a significance level of $5 \%(\alpha=$ $0.05)$ and with a sample number of 175 respondents $(n=175)$ need to be determined its Dtable value by using the formula,

$$
D_{\text {tabel }}=\frac{1,36}{\sqrt{n}}
$$

$\mathrm{n}=$ number of samples/respondents

Using the above formula, obtained $\mathrm{D}_{\text {table }}$ value for number of samples $175(n=175)$ that is equal to 0.1028 or rounded to $0.103\left(\mathrm{D}_{\text {table }}=0.103\right)$. From all normality of estimated regression error test for each hypotheses is expressed entirely from normal-distributed population and comply the normality requirements for linear regression and can be continued for further testing stage. Summary of the test result can be seen in Table 1 as follows,

Table 1 : Summary of Normality of Estimated Regression Error Test

\begin{tabular}{|c|c|c|c|c|c|c|}
\hline Ho & Estimated error & D.m. & Dus & Criteria & Decision & Canchusion \\
\hline 1 & $\mathrm{X}_{i} \infty \mathrm{X}_{\mathrm{i}}$ & 8061 & 0,103 & $\mathrm{D}_{0}<\mathrm{D}_{\boldsymbol{L}}$ & $\mathrm{H}_{4}$ be accepted & Nanmal \\
\hline 2 & $\mathrm{X}_{4} \infty \mathrm{X}_{\mathrm{g}}$ & 0.056 & 0.103 & $D_{0}<D_{\text {mit }}$ & $\mathrm{H}_{4}$ be acuepted & Narmal \\
\hline 3 & $X_{4} \infty X_{0}$ & 0.057 & 0.103 & $D_{0}<D_{\text {un }}$ & $\mathrm{H}_{9}$ be aceephed & Nonnd \\
\hline 4 & $Y$ on $X_{4}$ & 0,065 & 0,103 & $D_{0}<D_{\nu} \leq$ & $\mathrm{H}_{4}$ be aceegted & Normal \\
\hline 3 & $Y$ on $X_{1}$ & 0,067 & 0,103 & $D_{0}<D_{2}$ & Ho be acoepted & Narmal \\
\hline 6 & $Y \circ X_{3}$ & 0,065 & 0,103 & $D_{0}<D_{m}$ & $\mathrm{H}_{3}$ be weceped & Narmal \\
\hline 7 & Yon $X_{1}$ & 0,033 & 0,103 & $D_{0}<D_{2} \leqslant$ & Ha be ascoepted & Nomal \\
\hline
\end{tabular}

\subsubsection{Significance and Regression Linearity Test}

This test is intended to look at the equation of variable paired regression analyzed individually with the assumption that if individually all pairs exhibit symptoms of the same movement, then it will also occur if a full review is conducted. 
Summary of the test result can be seen in Table 2 below,

Table 2: Summary of Significance and Regression Linearity Test

\begin{tabular}{|c|c|c|c|c|c|}
\hline $\mathbf{E}$ & Regression Equation & Foner & Fuet & Decisinn & Conchusinn \\
\hline \multirow{2}{*}{1} & \multirow{2}{*}{$x_{1}$ on $X_{1}$} & 4,948 & 3,806 & $F_{\text {wat }}>F_{\text {wis }}$ & Significant \\
\hline & & 1,273 & 1,454 & $P_{\text {tene }}<F_{\text {sit }}$ & Linear \\
\hline \multirow{2}{*}{2} & \multirow{2}{*}{$X_{4}$ on $X_{2}$} & 4.940 & 3,896 & $\mathrm{~F}_{\text {mom }}>\mathrm{F}_{\mathrm{w}}$ & Sigtisicant \\
\hline & & 0,876 & 1,437 & Fom $<$ Fons & Linear \\
\hline \multirow{2}{*}{3} & \multirow{2}{*}{$X_{i}$ an $X_{i}$} & 5,345 & 3,896 & Freal $>$ Futs & significast \\
\hline & & 1,488 & 1,508 & $\mathrm{~F}_{\text {mese }}<\mathrm{F}_{\text {mas }}$ & Linzar \\
\hline \multirow{2}{*}{4} & \multirow{2}{*}{$Y \in X_{1}$} & 5,053 & 3,896 & $F_{m e n}>F_{m b}$ & SigniGicaut \\
\hline & & 0,698 & 1,454 & $\mathrm{~F}_{\text {men }}<\mathrm{F}_{\mathrm{m}}$ & Lineas \\
\hline \multirow{2}{*}{5} & \multirow{2}{*}{$Y \propto X_{1}$} & 5,947 & 3,896 & $\mathrm{~F}_{\text {mat }}>\mathrm{F}_{\text {mat }}$ & Significant \\
\hline & & 0,608 & 1,454 & $F_{\text {mat }}<F_{\text {ow }}$ & Linear \\
\hline \multirow{2}{*}{6} & \multirow{2}{*}{$Y \infty X_{i}$} & 4,473 & 3,896 & $P_{m a}>F_{m b}$ & Significant \\
\hline & & 0.614 & 1,508 & $F_{\text {men }}<F_{\text {min }}$ & Lineat \\
\hline \multirow{2}{*}{7} & \multirow{2}{*}{$Y \infty X_{4}$} & 11,457 & 3,896 & $F_{m e x}>F_{w o s}$ & Significans \\
\hline & & 1.296 & 1,437 & 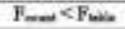 & Linear \\
\hline
\end{tabular}

\subsection{Line Model Testing}

The next stage of analysis is the testing of 2 substructural line models using the SPSS version 23 program. The first sub-structural model named "Job Satisfaction Model" and this model is intended to test hypotheses 1, 2, and 3. The second sub-structural model named "Turnover Intention Model" and this model is intended to test hypotheses 4, 5, 6 and 7 .

The test results for each sub-structural model are described in the following sections.

\subsubsection{Line Testing of Job Satisfaction Model}

In job satisfaction model, placed job satisfaction variable $\left(\mathrm{X}_{4}\right)$ as dependent variable and emotional intelligence $\left(\mathrm{X}_{1}\right)$, quality of work life $\left(\mathrm{X}_{2}\right)$ and stress $\left(\mathrm{X}_{3}\right)$ as independent variable. From the test result as shown in Table 3 obtained value of Adj. $\mathrm{R}^{2}=0.844$ and then calculated $\mathrm{e}_{1}\left(\right.$ error $\left._{1}\right)$ value by using the formula,

$$
e_{1}=\sqrt{1-\operatorname{Adj} \cdot R^{2}}
$$

From the calculation using the formula above obtained $\mathrm{e}_{1}$ value $=0.395$. To determine the magnitude of other variables outside the model that affect the job satisfaction model performed by calculating $\mathrm{e}_{1}^{2}=0,3952^{2}=0,156=15,6 \%$.

Table 3: Output of Model Summary of Job Satisfaction Model

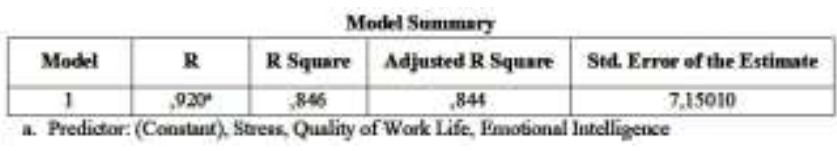

Table 4: Output of Coefficient of Job Satisfaction Model

\begin{tabular}{|c|c|c|c|c|c|}
\hline \multicolumn{6}{|c|}{ Coeffiriests" } \\
\hline \multirow{2}{*}{ Moded } & \multicolumn{2}{|c|}{$\begin{array}{l}\text { Unitandardiand } \\
\text { CoefFicients }\end{array}$} & \multirow{2}{*}{ Beta } & \multirow[t]{2}{*}{$t$} & \multirow{2}{*}{ Sig. } \\
\hline & B & Std Errur & & & \\
\hline \multirow{4}{*}{$\begin{array}{l}\text { 1. (Cossime), Stress } \\
\text { Qualify of Work Life, } \\
\text { Eroational Intelligener }\end{array}$} & 44,253 & 7,156 & & 6,184 &, 000 \\
\hline & .200 &, 072 & ,155 & 2,787 &, 006 \\
\hline & .796 & .068 & .767 & 16,196 &, 000 \\
\hline & $-05 z$ & , 046 & .047 & $-2,131$ & .040 \\
\hline
\end{tabular}

In table 4 above, it can be found path coefficient values between variables,

- Emotional intelligence $\left(X_{1}\right)$ on job satisfaction $\left(X_{4}\right)=0,155\left(\rho_{41}=0,155\right)$ confirmed with $\mathrm{t}_{\text {count }}=2,787$.

- Quality of work life $\left(\mathrm{X}_{2}\right)$ on job satisfaction $\left.\left(X_{4}\right)=0,767 \rho_{42}=0.767\right)$ confirmed with $\mathrm{t}_{\text {count }}=16,196$.

- Stress $\left(\mathrm{X}_{3}\right)$ on job satisfaction $\left(\mathrm{X}_{4}\right)=$ $0,047\left(\rho_{43}=-0,047\right)$ confirmed with $\mathrm{t}_{\text {count }}=$ $-2,131$.

Then to clarify the relationship path between variables $X_{1}, X_{2}$ and $X_{3}$ to $X_{4}$ is described a model in Figure 1 as follows,

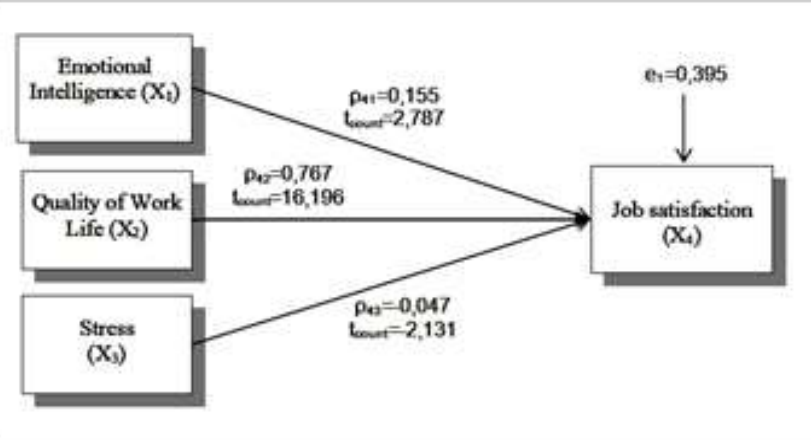

Figure 1 : Relationship Model of Job Satisfaction Model

\subsubsection{Line Testing of Turnover Intention Model}

In the job satisfaction model, there are variables of turnover intention $(\mathrm{Y})$ as dependent variable and emotional intelligence $\left(\mathrm{X}_{1}\right)$, quality of work life $\left(\mathrm{X}_{2}\right)$, stress $\left(\mathrm{X}_{3}\right)$, and job satisfaction $\left(\mathrm{X}_{4}\right)$ as independent variable. From the test results as shown in Table 5 obtained value of Adj. $\mathrm{R}^{2}=$ 0.660 and then calculated $\mathrm{e}_{2}\left(\right.$ error $\left._{2}\right)$ value by using the formula,

$$
e_{2}=\sqrt{1-A d j \cdot R^{2}}
$$

From the calculation results using the formula above obtained $\mathrm{e}_{2}$ value $=0.583$. To determine the 
magnitude of other variables outside the model that affect the turnover intention model performed by calculating $\mathrm{e}_{2}^{2}=0,58322=0,340=34 \%$.

Table 5 : Output of Model Summary of Turnover Intention Model

\begin{tabular}{|c|c|c|c|c|}
\hline Model & R & R Square & Adjusted R Square & Stil. Errur of the Estiante \\
\hline 1 &, 817 &, 608 &, 660 & 7,45020 \\
\hline
\end{tabular}

Table 6 : Output of Coefficient of Turnover Intention Model

\begin{tabular}{|c|c|c|c|c|c|}
\hline \multicolumn{6}{|c|}{ Coemicients } \\
\hline \multirow{2}{*}{ Model } & \multicolumn{2}{|c|}{ Unstandardized Coetreients } & \multirow[b]{2}{*}{ Beta } & \multirow{2}{*}{ t } & \multirow{2}{*}{ Sig. } \\
\hline & $\mathbf{B}$ & Stal. Erroe & & & \\
\hline \multirow{5}{*}{ 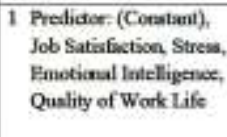 } & 26,141 & 8,248 & & 3,169 &., 002 \\
\hline &,- 972 &, 077 & 862 & $-12,087$ &, 000 \\
\hline & -144 &, 112 &,- 143 & $-2,287$ &, 047 \\
\hline & .090 & ,048 & ,115 & 2,876 & .042 \\
\hline & -466 & .080 & -650 & $-5,845$ &, 000 \\
\hline
\end{tabular}

In table 6, it can be found path coefficients values between variables,

- Emotional intelligence $\left(\mathrm{X}_{1}\right)$ on turnover intention $(\mathrm{Y})=-0.962\left(\rho_{\mathrm{y} 1}=-0,862\right)$ confirmed with $\mathrm{t}_{\text {count }}=-12.687$.

- Quality of work life $\left(X_{2}\right)$ on turnover intention $(\mathrm{Y})=-0.143\left(\rho_{\mathrm{y} 2}=-0.143\right)$ confirmed with $\mathrm{t}_{\text {count }}=-2,278$.

- Stress $\left(\mathrm{X}_{3}\right)$ on turnover intention $(\mathrm{Y})=$ $0,115\left(\rho_{\mathrm{y} 3}=0,115\right)$ confirmed with $\mathrm{t}_{\text {count }}=$ 2,876 .

- Job satisfaction $\left(\mathrm{X}_{4}\right)$ on turnover intention $(Y)=-0.659\left(\rho_{\mathrm{y} 4}=-0.659\right)$ confirmed with $\mathrm{t}_{\text {count }}=-5,845$.

Then to clarify the relationship path between variables $\mathrm{X}_{1}, \mathrm{X}_{2}, \mathrm{X}_{3}$ and $\mathrm{X}_{4}$ to $\mathrm{Y}$ is described a model in Figure 2 as follows,

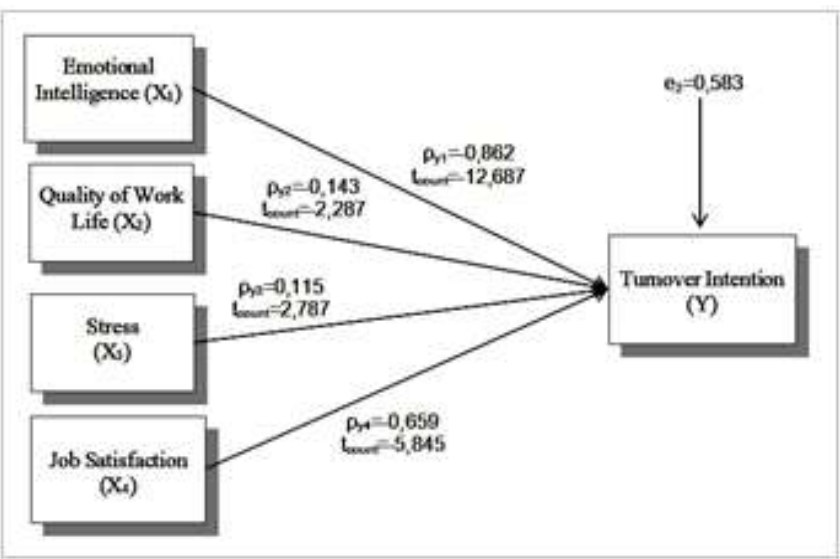

Figure 2 : Relationship Model of Turnover Intention Model

\subsection{Hypotheses Testing}

After all assumptions are met then the next step is to test the hypotheses as it has been proposed in the previous section. Tests on 7 partial hypotheses in this study were conducted based on $t_{\text {count }}$ value of each path of the causality relationship between the hypothesized variables. The following summarizes the results of all hypotheses testing in Table 7 below,

\section{Table 7 : Summary of Hypothesis Testing} Results

\begin{tabular}{|c|c|c|c|c|c|c|}
\hline $\mathbf{H}_{6}$ & Influence & $\rho$ & trous & trate & Criteris & Deeikion \\
\hline 1 & $\mathrm{X}_{\mathrm{t}} \rightarrow \mathrm{X}_{\mathrm{i}}$ & 0,155 & 2,787 & 1.974 & $t_{0,}>t_{40}$ & $\mathrm{H}_{3}$ rejected \\
\hline 2 & $x_{2} \rightarrow x_{4}$ & 0,767 & 16.196 & 1.974 & $t_{n z}>b_{0}$ & $\mathrm{H}_{1}$ rejected \\
\hline 3 & $\mathrm{X}_{3} \rightarrow \mathrm{X}_{4}$ & $-0,047$ & $-2,131$ & -1.974 & $t_{n t}<b_{b t}$ & $\mathrm{H}_{2}$ rejected \\
\hline 4 & $X_{1} \rightarrow Y$ & -0.862 & $-12,687$ & -1.974 & $t_{t} x<t=0$ & Hi) rejested \\
\hline 5 & $\mathrm{X}_{2} \rightarrow \mathrm{Y}$ & $-0,143$ & $-2,287$ & -1974 & $t_{2 x}<t_{b}$ & $H_{3}$ rejected \\
\hline 6 & $X_{3} \rightarrow Y$ & 0.115 & 2,876 & 1.974 & $\mathrm{tax}_{2}>\mathrm{tab}_{0}$ & Ha rejected \\
\hline 7 & $\mathrm{X}_{t} \rightarrow \mathrm{Y}$ & $-0,659$ & $-5,845$ & -1.974 & $\mathrm{~b}_{\mathrm{a}}<\mathrm{bu}$ & Ha rejected \\
\hline
\end{tabular}

\section{Conclusion}

Based on the results of research and discussion that has been presented in the previous sections, the conclusions obtained from this study are:

1. Emotional intelligence has a direct positive effect on job satisfaction. This means that employee emotional intelligence increase will lead to employee job satisfaction increase, and otherwise employee emotional intelligence decrease will lead to employee job satisfaction decrease.

2. Quality of work life has a direct positive effect on job satisfaction. This means that employee quality of work life increase will lead to employee job satisfaction increase, and otherwise employee quality of work life decrease will lead to employee job satisfaction decrease.

3. Stress has a direct negative effect on job satisfaction. This means that employee stress increase will lead to employee job satisfaction decrease, and otherwise employee stress decrease will lead to employee satisfaction increase.

4. Emotional intelligence has a direct negative effect on intention of turnover. This means that employee emotional intelligence increase will lead to employee 
turnover intention decrease, and otherwise employee emotional intelligence decrease will lead to employee turnover intention increase.

5. Quality of work life has a direct negative effect on turnover intention. This means that employee quality of work life increase will lead to employee turnover intention decrease, and otherwise employee quality of work life decrease will lead to employee turnover intention increase.

6. Stress has a direct positive effect on turnover intention. This means that employee stress increase will lead to employee turnover intention increase, and otherwise employee stress decrease will lead to employee turnover decrease.

7. Job satisfaction has a direct negative effect on turnover intention. This means that employee job satisfaction increase will lead to employee turnover intention decrease, and otherwise employee job satisfaction decrease will lead to employee turnover intention increase.

\section{References}

[1] R.L. Mathis \& J.H. Jackson, Human Resource Management, $12^{\text {th }}$ Edition, Thompson South-Western, Mason, 2008.

[2] M. Lewis, "Causal Factors that Affect Turnover Intent in Manufacturing Organization," Thesis, University of Pretoria, South Africa, 2008.

[3] L.Y. Chen \& A.M. Francesco, "Employee demography, organizational commitment, and turnover intentions in china: Do cultural differences matter?," Human Relations, 53(6), pp. 869-887, 2000.

[4] M. Armstrong, A Handbook of Human Resource Management Practice, $10^{\text {th }}$ Edition, Kogan Page, London, 2006.

[5] F. Luthans, Organizational Behaviour An Evidence-Based Approach, 12 ${ }^{\text {th }}$ Edition, Mc.Graw-Hill, New York, 2011.

[6] H. Weisinger, Emotional Intelligence at Work, Wiley India Pvt. Ltd., India, 2006.
[7] Kinicki, et al., Organizational Behaviour, $3^{\text {rd }}$ CDN Edition, Mc.Graw-Hill Ryerson Higher Education, New York, 2010.

[8] D. Goleman, Emotional Intelligence, Why It Can Matter Than IQ, Bloomsbury Publishing Plc., London, 2009.

[9] M. Armstrong, Strategic Human Resource Management, A Guide to Action, $4^{\text {th }}$ Edition, Kogan Page, London, 2008.

[10] W.F. Cascio, Managing Human Resources, $6^{\text {th }}$ Edition: Productivity, Quality of Work Life, Profits, Mc.GrawHill, U.S.A., 2003.

[11]J. Walton, Provided a Model That Can Be Useful To Understand This Sense Better, Quality of work life (QWL) in Walton's Model, 1998.

[12]D. Hellriegel \& J.W. Slocum, Jr., Organizational Behaviour, $13^{\text {th }}$ Edition, South Western Cencage Learning, Ohio, 2011.

[13]J.R. Schermerhorn, et.al., Organizational Behaviour, $7^{\text {th }}$ Edition, Wiley Publisher, New Jersey, 2002.

\section{Author Profile}

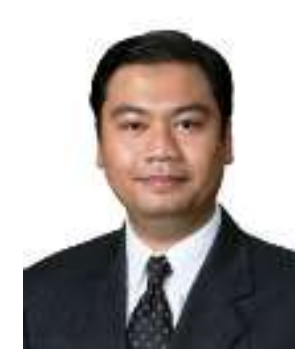

Tossy Aryanto, received B.E. (Bachelor of Economic) in Management from Trisakti University, Jakarta in 1996 and M.M. (Master of Management) from Bogor Agricultural University, Bogor in 2001. Since 1994 has been engaged in practical business in the field of fire and safety industry. Active in political and organizational activities and has served as a member of parliament of the Republic of Indonesia for the term of office 2009-2014. Started doctoral studies at Jakarta State University in 2015, majored in Human Resource Management (HRM). 